\title{
Factors influencing CD4 cell count in HIV-positive pregnant women in a secondary health center in Lagos, Nigeria
}

This article was published in the following Dove Press journal:

HIVIAIDS - Research and Palliative Care

10 April 2015

Number of times this article has been viewed

\section{Akinsegun A Akinbami' \\ Abidoye Gbadegesin ${ }^{2}$ \\ Sarah O Ajibola ${ }^{3}$ \\ Ebele I Uche' \\ Adedoyin O Dosunmu' \\ Adewumi Adediran ${ }^{4}$ \\ Adekunle Sobande ${ }^{2}$}

'Department of Haematology and Blood Transfusion, ${ }^{2}$ Department Of Obstetrics and Gynaecology, College of Medicine, Lagos State University, Ikeja, Lagos, Nigeria; ${ }^{3}$ Department of Haematology and Immunology, Ben-Carson School of Medicine, Babcock University, Ilisan, Ogun State, Nigeria; ${ }^{4}$ Department of Haematology and Blood Transfusion, Faculty of Clinical Sciences, College of Medicine, University of Lagos, Lagos, Nigeria

Correspondence: AA Akinbami Department of Haematology and Blood Transfusion, College of Medicine, Lagos State University, Ikeja, Lagos, Nigeria

Tel +234 I 8023064925

Email ajoke_clinic@yahoo.co.uk
Background: Immunity in pregnancy is physiologically compromised, and this may affect CD4 count levels. It is well-established that several factors affect CD4 count level in pregnancy. This study aimed to determine the mean and reference range of CD4 count in human immunodeficiency virus (HIV)-positive pregnant women in Lagos, Nigeria.

Methods: A retrospective study was carried out at antenatal clinics of the Maternal and Child Center of a secondary health center in Lagos State, Nigeria. Records of HIV-positive pregnant women at various gestational ages, including CD4+ cell count at booking, packed cell volume (PCV) at booking and labor, gestational age at delivery, and infant weight and sex were retrieved. The descriptive data was given as mean \pm standard deviation (SD). Pearson's chi-squared test and correlation were used for analytical assessment

Results: Data were retrieved for a total of 143 patients. The mean age was $31.15 \pm 3.78$ years. The mean PCV was $31.01 \% \pm 3.79 \%$ at booking and $30.49 \% \pm 4.80 \%$ during labor. The mean CD4 count was $413.87 \pm 212.09$ cells $/ \mu \mathrm{L}$, with a range of 40 to 1,252 cells/ $\mu \mathrm{L}$. The mean infant weight was $3.05 \pm 0.45 \mathrm{~kg}$, with a range of 2 to $5 \mathrm{~kg}$. Age of the mother, gestational age, and $\mathrm{PCV}$ at booking were not statistically significantly associated with CD4 count.

Conclusion: Maternal age, gestational age, and PCV at booking had no significant effects on CD4+ cell count levels in pregnancy. The mean CD4+ cell count of HIV-positive pregnant women in Lagos is $413.87 \pm 212.09$ cells $/ \mu \mathrm{L}$.

Keywords: mean value, reference range, HIV-pregnant women, immunity, pregnancy

\section{Introduction}

CD4-receptors containing cells are the portal of entry of human immunodeficiency virus (HIV), and the rate of CD4 cell destruction is directly proportional to progressive replication of HIV. Immune system destruction is inevitable if the rate of HIV replications outstrips the CD4 cells available. The mechanism of CD4 cell destruction is dependent on whether HIV infection is in acute or chronic phase. ${ }^{1}$

Destruction of CD4 cells is affected by cytotoxic T cells and apoptosis in the acute phase, while inability of the immune system to produce new T cells and generalized immune activation accounts for the CD4 cell depletion in chronic phase. ${ }^{2}$

CD4 T-lymphocytes and other lymphocytes coordinate the immune system response to pathogens. ${ }^{3}$ In HIV-infected individuals, the CD4+ cell count provides a picture of immune system health, with higher CD4 counts typically signifying healthier immune systems. Pregnancy is associated with altered immunity, and it may worsen the immunosuppression associated with an HIV infection. ${ }^{4}$ However, Saada et al reported that pregnancy in HIV-infected women did not cause deterioration in CD4 count. ${ }^{5}$ This study 
may bring to the fore variability in CD4+ cell counts as a result of pregnancy and HIV. It may also offer explanations for these differences.

\section{Materials and methods Study design}

A retrospective study was carried out at the antenatal clinics of the Maternal and Child Center at Ifako Ijaiye General Hospital in Lagos State, Nigeria, amongst patients who registered from January 2011 to February 2014. Ethics approval was obtained from the institution's Health Research and Ethics Committee. Data retrieved included CD4 count at booking, packed cell volume (PCV) at booking, during labor and discharge, gestational age at delivery, and infant weight and sex. All the patients were highly active antiretroviral therapy (HAART)-experienced because of Prevention of Maternal to Child Transmission.

The descriptive data was given as mean \pm standard deviation (SD). Pearson's chi-squared test and correlation were used for analytical assessment. The differences were considered statistically significant when the $P$-value obtained was $<0.05$.

\section{Results}

A total of 143 records were retrieved. The mean age was $31.15 \pm 3.78$ years, with a minimum of 23 and maximum of 47 years. Stratifying maternal ages indicated that ten (6.7\%) were between 20-24 years, 37 (24.7\%) were between 25-29 years, and 96 (64\%) were older than 30 years; all were older than 20 years. The booking PCV was $31.01 \% \pm 3.79 \%$, with a minimum of $22 \%$ and maximum of $47 \%$. The mean PCV during labor was $30.49 \% \pm 4.80 \%$, with a minimum of $18 \%$ and maximum of $40 \%$.

The mean CD4 count was $413.87 \pm 212.09$ cells $/ \mu L$. The minimum CD 4 count was 40 cells $/ \mu \mathrm{L}$, and maximum was 1,252 cells $/ \mu \mathrm{L}$. The mean infant weight was $3.05 \pm 0.45 \mathrm{~kg}$, with a minimum of $2 \mathrm{~kg}$ and maximum of $5 \mathrm{~kg}$ (Table 1).

A total of one 140 babies were delivered, consisting of $76(50.7 \%)$ males and $74(49.3 \%)$ females. The majority of

Table I Parameters

\begin{tabular}{lcl}
\hline Parameter & Mean \pm SD & Range \\
\hline Age (years) & $31.15 \pm 3.78$ & $23-47$ \\
Booking PCV (\%) & $31.01 \pm 3.79$ & $22-47$ \\
PCV in labor (\%) & $30.49 \pm 4.80$ & $18-40$ \\
CD4+ count (cells/ $\mu \mathrm{L})$ & $413.87 \pm 212.09$ & $40-1,252$ \\
Infant weight $(\mathrm{kg})$ & $3.05 \pm 0.45$ & $2-5$ \\
\hline
\end{tabular}

Abbreviations: PCV, packed cell volume; SD, standard deviation. the deliveries were spontaneous vertex deliveries (79 of 150 [52.7\%]), while $71(47.3 \%)$ required emergency cesarean section.

The age of the pregnant woman, gestational age, and PCV at booking, when compared with CD4 count of the participants, were not statistically significant by Pearson's chi-squared test $(P$-values were $0.11,0.12$, and 0.46 , respectively). Stratified maternal ages were also not statistically significant when compared with CD4 count of the participants $(P=0.35)$. However, they all correlated positively using Pearson's correlation test $(r=0.18,0.27,0.01$, and 0.12 , respectively) (Table 2 ).

\section{Discussion}

Immunity in pregnancy is physiologically compromised and may affect the CD4+ cell count, as lower CD4+ cell count has been reported in pregnant compared with nonpregnant females. ${ }^{4}$ The reference range for the CD4+ cell count amongst Nigerians was reported earlier by Aina et $\mathrm{al}^{6}$ and Oladepo ${ }^{7}$ et al, and the effects of various variables on CD4+ cell count levels in pregnancy were highlighted. This study considered and established that maternal age, gestational age, and PCV at booking did not influence the CD4+ cell count in HIV-infected pregnant women.

This study population fell in the age range of 23-47 years. Stratified maternal ages and CD4+ cell counts were found to be insignificantly related, and this was contrary to the study of Abimiku et al, ${ }^{8}$ which reported, in 2009, that low CD4+ cell count was significantly associated with older age, lack of condom use, history of genital ulcers, and history of vaginal discharge.

CD4+ cell count is highest during the early years of life. It declines steadily to stable adult values, and it is lowest in the elderly. ${ }^{9}$ However, Aina et $\mathrm{al}^{6}$ reported that in pregnant women, unlike men and nonpregnant females, the odds of having a low CD4+ cell cell count were significantly related to both age by decade and age at marriage by decade. They suggested that the effect of marriage age may be due to prolonged exposure to sexually transmitted diseases and other infections, with the development of chronic lymphocytosis, in women who got married earlier.

Table 2 Bivariate analysis

\begin{tabular}{lll}
\hline Parameter & P-value & $\boldsymbol{r}$ \\
\hline Maternal age vs CD4+ cells & 0.109 & 0.179 \\
Gestational age vs CD4+ cells & 0.119 & 0.269 \\
PCV at booking vs CD+ cells & 0.463 & 0.098 \\
\hline
\end{tabular}

Abbreviation: PCV, packed cell volume. 
This study also reported an insignificant association between $\mathrm{CD} 4+$ cell count and gestational age. Gestational age may or may not affect CD4+ cell count, as some authors reported an increase in CD4+ cells count as gestational age increased. ${ }^{10}$ Another study reported no relationship exists between gestational age and CD4+ cell count in both HIVpositive and HIV-negative women. ${ }^{11}$ However, Gomo et al ${ }^{12}$ reported a decline in CD4+ cell count, by 25 cells $/ \mu \mathrm{L}$ for each week increase in gestation, among women with low serum retinol.

The mean CD4+ cell count of $413.87 \pm 212.09$ cells $/ \mu \mathrm{L}$ reported in this study is similar to 402 cells $/ \mu \mathrm{L}$, reported by Myer et a ${ }^{13}$ in 2013. A lower value, of $323.7 \pm 170.7$ cells $/ \mu \mathrm{L}$ in HIV-positive pregnant women, was obtained in Nigeria by Ekwempu et al. ${ }^{14}$ From these data, one may generate a range of mean CD4 count, between 323.7-413.8 cells $/ \mu \mathrm{L}$, in HIV-positive pregnant women.

The mean CD4+ value of 413.87 cells $/ \mu \mathrm{L}$ obtained in HIV-positive pregnant women in this study is higher than the mean $317.55 \pm 254.72$ cells $/ \mu \mathrm{L}$ reported by Akinbami et $\mathrm{al}^{15}$ in nonpregnant HIV-positive women. Use of HAART by participants in the present study could be responsible for the higher CD4+ cell values obtained than those reported in the nonpregnant HIV-positive women, who were HAARTnaïve, in the previous study. Both values are, however, almost half of the 771 cells $/ \mu \mathrm{L}$ obtained in HIV-negative pregnant women by Akinbami et al ${ }^{16}$ and Aina et al. ${ }^{6}$ The CD4 cell count could also be compared with values obtained in nonpregnant HIV-seronegative women, of 828 cells $/ \mu \mathrm{L}$ and 847 cells $/ \mu \mathrm{L}$, obtained by Aina et $\mathrm{al}^{6}$ and Oladepo et al, ${ }^{7}$ respectively. A marginal difference, of between 57-76 cells/ $\mu \mathrm{L}$, was observed in HIV-negative pregnant women and nonpregnant $\mathrm{HIV-seronegative} \mathrm{women,} \mathrm{unlike} \mathrm{a} 50 \%$ reduction in CD4+ cells found between HIV-positive pregnant women/ nonpregnant HIV-positive women ${ }^{15}$ and either HIV-negative pregnant women ${ }^{16}$ or nonpregnant HIV-seronegative women. ${ }^{6}$ This brings to the fore the effects of HIV on CD4+ count value. The marked drop in CD4+ cell count as a result of HIV infection, in the presence or absence of pregnancy, is explainable by the fact that viral replication starts within cells with CD4 receptors at the site of HIV entry. The infected cells can then release virions by surface budding, and infected cells undergo lysis, with release of new HIV virions, which can then infect additional cells.

A CD4+ cell count reference range of $40-1252$ cells $/ \mu \mathrm{L}$ was obtained in this study. The lower limit of 40 cells $/ \mu \mathrm{L}$ for the CD4 counts obtained in the study may be a reflection of the study by Abimiku et al, ${ }^{8}$ which reported $36.6 \%$ of HIV- positive pregnant Nigerian women had CD4+ cell counts of $\leq 200 \mathrm{cells} / \mu \mathrm{L}$. Underlying infectious diseases have been associated with decreased CD4 levels. ${ }^{17}$ The pregnant women in this study were not screened for any underlying infectious diseases, eg, pulmonary tuberculosis, which could impact on the result. However, the upper limit of 1,252 cells $/ \mu \mathrm{L}$ obtained in our study is similar to the 1,314 cells $/ \mu \mathrm{L}$ upper limit reported by Aina et $\mathrm{al}^{6}$ amongst HIV-negative pregnant women.

\section{Conclusion}

Maternal age, gestational age, and PCV at booking had no significant effects on $\mathrm{CD} 4+$ cell count levels in pregnancy. The mean CD4+ cell count of HIV-positive pregnant women in Lagos is $413.87 \pm 212.09$ cells $/ \mu \mathrm{L}$.

\section{Acknowledgments}

We acknowledge the duo of Fatimoh Mohmoh and the late Blessing Otong, who assisted greatly in data retrieval.

\section{Author contributions}

AA was responsible for conceptualization and design of the study. AG performed the literature search. IE performed data entry. AO performed data analysis. $\mathrm{SO}$ and $\mathrm{PO}$ reviewed the manuscript. All authors contributed toward data analysis, drafting and revising the paper and agree to be accountable for all aspects of the work.

\section{Disclosure}

The authors report no conflicts of interest in this work.

\section{References}

1. Hel Z, McGhee JR, Mestecky J. HIV infection: first battle decides the war. Trends Immunol. 2006;27(6):274-281.

2. Zuckerman AJ, Banatvala JE, Griffiths P, Schoub B, Mortimer P, editors. Principles and Practice of Clinical Virology. 6th ed. Hoboken, NJ: John Wiley and Sons Ltd; 2009.

3. Koenig S, Fausi A. Immunology of human immunodeficiency virus infection. In: Holmes KK, Mardh P, Sparling PA, Lemon SM, editors. Sexually Transmitted Diseases. Vol 3. New York, NY: McGraw-Hill; 1999: 231-249.

4. Hocke C, Morlat P, Chene G, Dequae L, Dabis F; Groupe d'Epidémiologie Clinique Du SIDA en Aquitaine. Prospective cohort study of the effect of pregnancy on the progression of human immunodeficiency virus infection. Obstet Gynecol. 1995;86(6):886-891.

5. Saada M, Le Chenadec J, Berrebi A, et al. Pregnancy and progression to AIDS: results of the French prospective cohorts. SEROGEST and SEROCO Study Groups. AIDS. 2000;14(15):2355-2360.

6. Aina O, Dadik J, Charurat M, et al; Institute of Human Virology/Plateau State Specialist Hospital AIDS Prevention in Nigeria Study Team. Reference values of CD4 T lymphocytes in human immunodeficiency virus-negative adult Nigerians. Clin Diagn Lab Immunol. 2005;12(4) 525-530

7. Oladepo DK, Idigbe EO, Audu RA, et al. Establishment of reference values of CD4 and CD8 lymphocyte subsets in healthy Nigerian adults. Clin Vaccine Immunol. 2009;16(9):1374-1377. 
8. Abimiku A, Villalba-Diebold P, Dadik J, Okolo F, Mang E, Charurat M. Risk factors associated with low CD4+ lymphocyte count among HIV-positive pregnant women in Nigeria. Int $J$ Gynaecol Obstet. 2009;106(3): 227-231.

9. Lugada ES, Mermin J, Kaharuza F et al. Population-based hematologic and immunologic reference values for a healthy Ugandan population. Clin Diagn Lab Immunol. 2004;11(1):29-34.

10. Tuomala RE, Kalish LA, Zorilla C, et al. Changes in total, CD4+, and CD8+ lymphocytes during pregnancy and 1 year postpartum in human immunodeficiency virus-infected women. The Women and Infants Transmission Study. Obstet Gynecol. 1997;89(6):967-974.

11. Temmerman M, Nagelkerke N, Bwayo J, Chomba EN, Ndinya-Achola J, Piot P. HIV-1 and immunological changes during pregnancy: a comparison between HIV-1-seropositive and HIV-1-seronegative women in Nairobi, Kenya. AIDS. 1995;9(9):1057-1060.

12. Gomo E, Vennervald BJ, Ndhlovu P, Kaestel P, Nyazema N, Friis H. Predictors and reference values of CD4 and CD8 T lymphocyte counts in pregnancy: a cross sectional study among HIV negative women in Zimbabwe. Cent Afr J Med. 2004;50(1-2):10-19.
13. Myer L, Daskilewicz K, McIntyre J, Bekker LG. Comparison of pointof-care versus laboratory-based CD4 cell enumeration in HIV-positive pregnant women. J Int AIDS Soc. 2013;16:18649. Abstract.

14. Ekwempu AI, Ekwempu CC, Ikeh E, Olabode A, Agaba E. Comparison of CD4 cell counts in pregnant HIV-seropositive and HIV-seronegative Nigerian women. Lab Med. 2012;43(5):168-171.

15. Akinbami A, Dosunmu A, Adediran A, et al. CD4 count pattern and demographic distribution of treatment-naïve HIV patients in Lagos, Nigeria. AIDS Res Treat. 2012;2012:352753.

16. Akinbami AA, Dosunmu AO, Adediran A, et al. Cluster of differentiation $4+$ cell count mean value, reference range and its influencing factors in Human Immunodeficiency Virus-seronegative pregnant women in Lagos. Niger Med J. 2014;55(2):116-120.

17. Fantin B, Joly V, Elbim C, et al. Lymphocyte subset counts during the course of community-acquired pneumonia: evolution according to age, human immunodeficiency virus status, and etiologic microorganisms. Clin Infect Dis. 1996;22(6):1096-1098.
HIV/AIDS - Research and Palliative Care

\section{Publish your work in this journal}

HIV/AIDS - Research and Palliative Care is an international, peerreviewed open-access journal focusing on advances in research in HIV, its clinical progression and management options including antiviral treatment, palliative care and public healthcare policies to control viral spread. The journal welcomes original research, basic science,

\section{Dovepress}

clinical \& epidemiological studies, reviews \& evaluations, expert opinion \& commentary, case reports \& extended reports. The manuscript management system is completely online and includes a very quick and fair peer-review system. Visit http://www.dovepress.com/ testimonials.php to read real quotes from published authors. 